\title{
Apoptotic Cell Death is a Common Response to Pathogen Attack in Oats
}

\author{
Nan Yao, Satoshi Imai, Yasuomi Tada, Hitoshi Nakayashiki, Yukio Tosa, Pyoyun Park, and \\ Shigeyuki Mayama \\ Laboratory of Plant Pathology, The Graduate School of Science and Technology, Kobe University, Rokkodai, Nada-ku, \\ Kobe 657-8501, Japan
}

Submitted 15 March 2002. Accepted 20 June 2002.

\begin{abstract}
We have examined the characteristics of cell death induced by pathogen infection in oats with respect to following hallmark apoptotic features: DNA laddering, chromatin condensation, and electron microscopic-terminal deoxynucleotidyl transferase-mediated UTP end labeling positive response. A wide range of plant pathogens representing different levels of parasitism in susceptible and resistant interactions were used for the inocula, which include (i) an obligate parasite, Puccinia coronata f. sp. avenae (the crown rust fungus); (ii) a facultative biotroph parasite, Magnaporthe grisea (the blast fungus); (iii) pathogenic bacteria, Pseudomonas syringae pv. atropurpurea and $P$. syringae pv. coronafaciens (the halo or stripe blights of oats); and (iv) Ryegrass mottle virus. Surprisingly, any of the pathogens used induced most of the apoptotic features in oat cells at and around the infection sites, indicating that apoptotic cell death is a common phenomenon in oats during pathogen attack. The localization and the timing of apoptotic cell death during a course of infection were, however, quite different depending on the interactions (compatible or incompatible) and the pathogens (fungi, bacteria, or viruses). Possible roles of apoptotic cell death in the susceptible and resistant interactions are discussed.
\end{abstract}

The activation of plant defense mechanisms upon pathogen infection is often accompanied by cell death, termed hypersensitive response (HR), at and around the infection sites. HR is a typical reaction of a resistant plant against an incompatible pathogen, where rapid and localized cell death occurs and the pathogen invasion is halted (Heath 2000). This response is invoked by infection with a wide range of pathogenic organisms, including fungi, bacteria, viruses, and nematodes (Morel and Dangl 1997). Recent studies have suggested that hypersensitive cell death is a genetically programmed response and shares a number of morphological and biochemical features with animal apoptosis (Dangl et al. 1996; Gilchrist 1998; Heath 1998; Lam et al. 2001; Pontier et al. 1998; Richberg et al. 1998; Tada et al. 2001). For example, cell death triggered in resistant cowpea plants by an incompatible cowpea rust fungus (Uromyces vignae) was accompanied by DNA laddering and a terminal deoxynucleotidyl transferase-mediated UTP end labeling (TUNEL)-positive response (Ryerson and Heath 1996). Also, caspase-like proteolytic activity (del Pozo and Lam 1998) and

Corresponding author: Shigeyuki Mayama, Telephone: +81-78-803-5864; Fax: +81-78-803-5865; E-mail: mayama@kobe-u.ac.jp.
$\mathrm{Ca}^{2+}$-dependent nucleases were detected in resistant tobacco plants during the process of HR upon infection with tobacco mosaic virus (Mittler and Lam 1995).

On the other hand, cell death is also a feature of disease symptoms during compatible plant-microbe interactions. It has been demonstrated that the cell death induced by compatible pathogens also exhibits some features similar to apoptosis in animals (Navarre and Wolpert 1999; Tada et al. 2001; Wang et al. 1996; Yao et al. 2001). Susceptible host plants infected with toxin-producing pathogenic fungi Alternaria alternata and Cochliobolus victoriae showed DNA fragmentation, TUNELpositive responses, and chromatin condensation (Navarre and Wolpert 1999; Tada et al. 2001; Wang et al. 1996; Yao et al. 2001). Cucumber mosaic virus D satellite RNA also has been shown to induce morphological features of apoptosis in infected tomato leaves (Xu and Roossinck 2000). Therefore, the mechanisms of cell death in compatible and incompatible interactions seem to have overlapping pathways (Dangl et al. 1996; Greenberg 1997). It still is not clear to what extent various death processes share common morphological and biochemical features, or how the process of cell death varies depending on the plant-pathogen combination used.

In animals, apoptosis is thought to be a ubiquitous phenomenon, wherein apoptotic signals activated by various stimuli eventually converge towards a common mechanism (Martin and Green 1995). A variety of environmental stresses are known to induce apoptosis in animal cells, such as insult by radiation (Veis et al. 1993), treatment with drugs (Fisher 1994; Hirpara et al. 2001), and infection by microorganisms (Gougeon et al. 1998). In the previous studies, we also have shown that oat plants (Avena sativa L.) display characteristics similar to animal apoptosis in response to several biological and chemical stresses (Mayama et al. 2001; Tada et al. 2001; Yao et al. 2001). These include (i) infection by an incompatible obligate fungal parasite, Puccinia coronata $\mathrm{f}$. sp. avenae; (ii) victorin, a host-specific toxin that is essential for the pathogenicity of Cochliobolus victoriae on oat plants carrying the $V b$ gene; (iii) nonspecific elicitors such as chitin and chitosan oligomers; and (iv) the calcium ionophore A23187.

Using oats as a model plant, here we present a survey of the incidence of disease-related plant cell death across a wide range of plant pathogens in compatible and incompatible interactions. The results showed that apoptotic-like features characterized by DNA laddering, DNA cleavage, and chromatin condensation were induced by infection with all of the pathogens used, suggesting that apoptotic cell death is a common response to pathogen attack in both compatible and incompatible interactions. 


\section{RESULTS}

\section{Cell death induced}

by an obligate parasite, the crown rust fungus.

The oat cultivar Shokan 1 is highly resistant to the crown rust fungus, $P$. coronata $\mathrm{f}$. sp. avenae race 226 , and susceptible to race 203. Our previous studies revealed that DNA laddering and chromatin condensation were detected by 24 to $36 \mathrm{~h}$ after inoculation in Shokan leaves infected with the incompatible race 226 (Mayama et al. 2001; Tada et al. 2001; N. Yao, H. Nakayashiki, Y. Tosa, S. Mayama, unpublished data), indicating that apoptotic cell death was rapidly induced in the incompatible interaction. To assess whether the compatible obligate parasite also induces an apoptotic response in oat cells, we focused on morphological events in the primary leaves of Shokan 1 during infection by the compatible race 203. In contrast to the incompatible interaction (Shokan 1-race 226), the fungus invasion proceeded into mesophyll cells and formed haus-
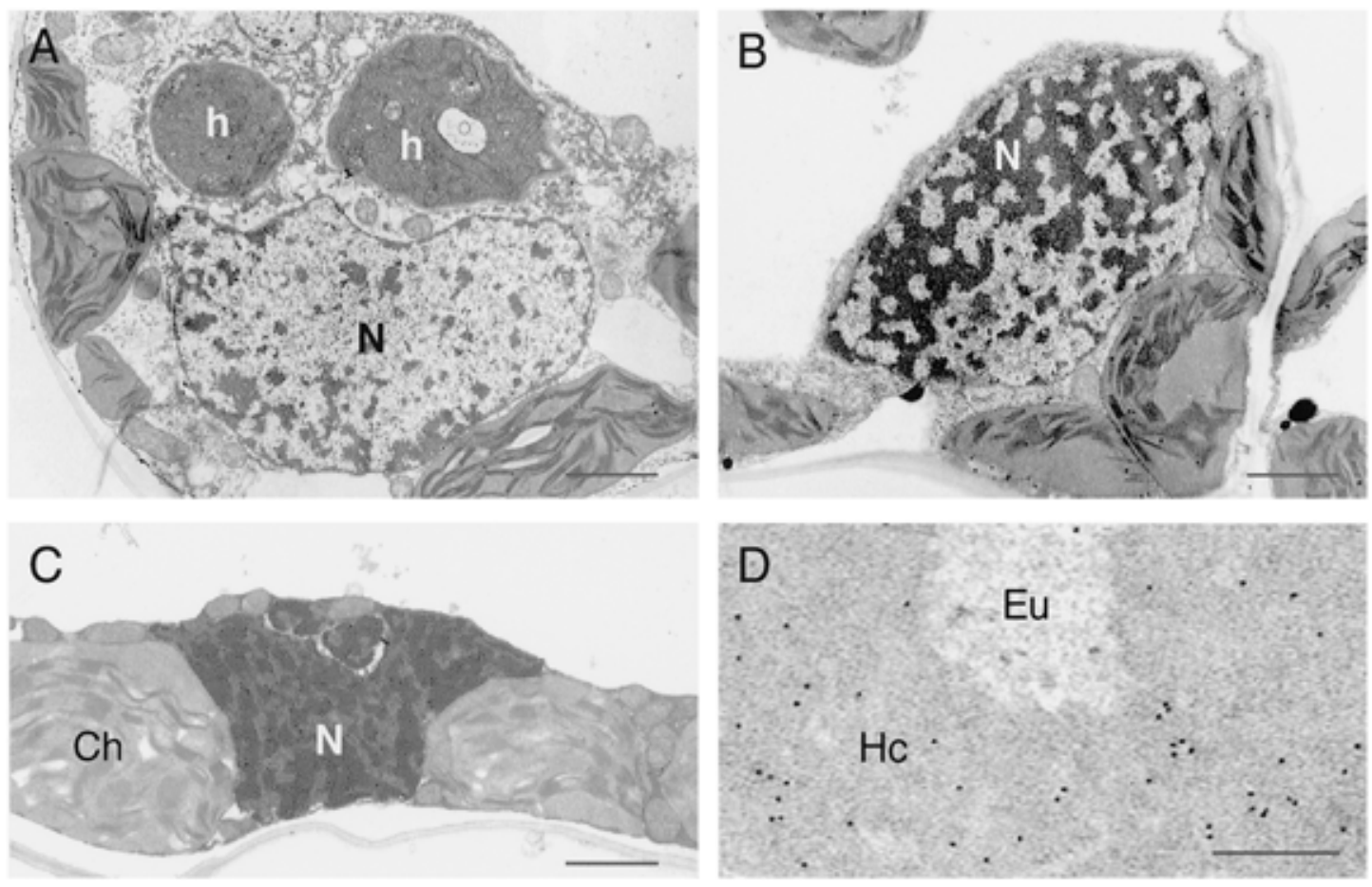

Fig. 1. Ultrastructural changes in oat mesophyll cells during infection of oat cv. Shokan 1 leaves with the compatible race 203 of Puccinia coronata f. sp. avenae. A, Cell $36 \mathrm{~h}$ after inoculation. Note a normal nucleus and rust haustoria. B, Cell adjacent to the cell containing haustoria $72 \mathrm{~h}$ after inoculation. $\mathbf{C}$, Cell adjacent to the haustorium-formed cell $96 \mathrm{~h}$ after inoculation. Note condensed chromatin and abnormal chloroplasts. D, Electron microscopic- terminal deoxynucleotidyl transferase-mediated UTP end labeling analysis of the immunolocalization of DNA strand breaks in the same sample as shown in C. The size of a gold particle is $10 \mathrm{~nm}$. Note the gold labeling of free $3^{\prime}-\mathrm{OH}$ ends, especially in the condensed heterochromatin portion. Ch $=$ chloroplast, $\mathrm{h}=$ haustorium, Eu = euchromatin, $\mathrm{Hc}=$ heterochromatin, $\mathrm{N}=$ nucleus. $\mathrm{Bar}=2 \mu \mathrm{m}(\mathrm{A}-\mathrm{C})$ and $200 \mathrm{~nm}(\mathrm{D})$.

A

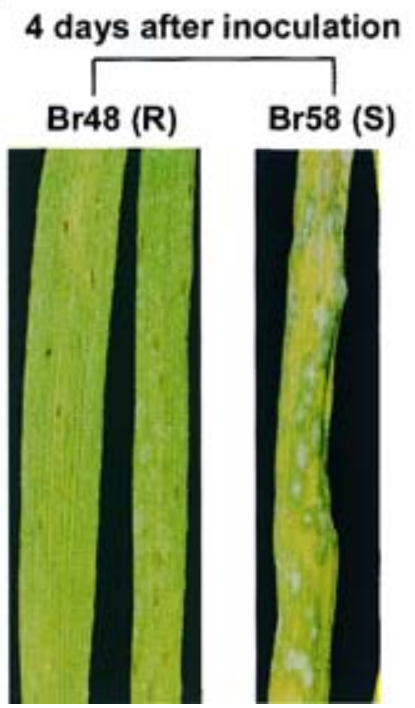

B

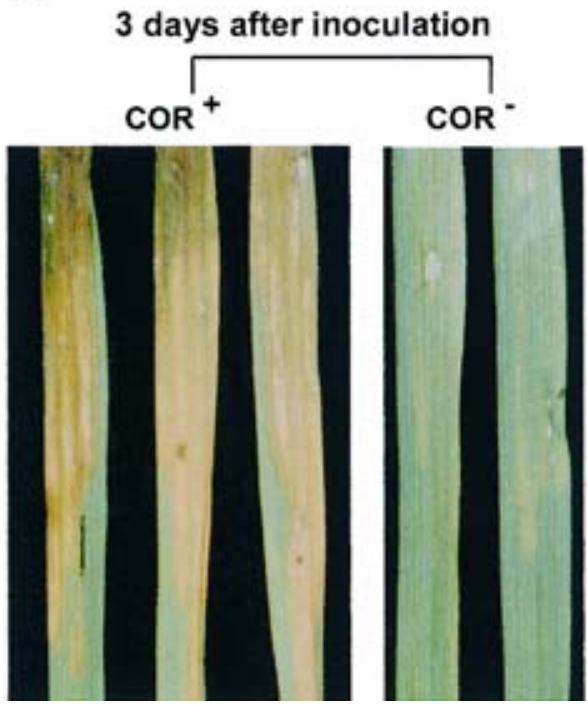

C

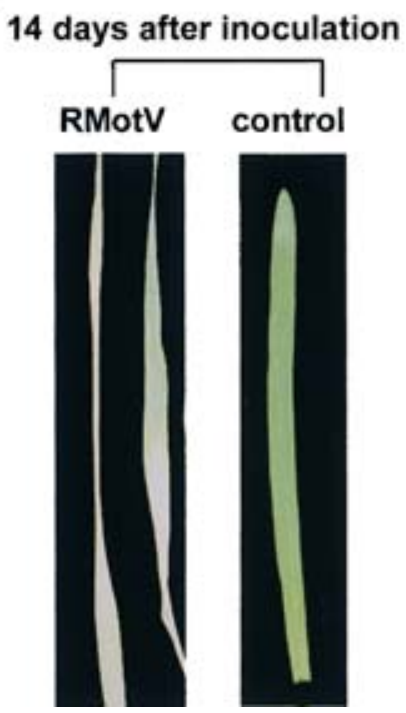

Fig. 2. Symptoms in oat leaves (cv. Shokan 1) inoculated with A, Magnaporthe grisea, Triticum isolate Br48, and Avena isolate Br58, B, coronatine-producing wild-type strain $\left(\mathrm{COR}^{+}\right)$and coronatine-defective mutant $\left(\mathrm{COR}^{-}\right)$of Pseudomonas syringae pv. atropurpurea, and $\mathbf{C}$, Ryegrass mottle virus (RMotV). In all combinations, primary leaves were inoculated. A and B, Primary leaves; $\mathbf{C}$, secondary leaves of seedlings. 
toria within oat cells by $36 \mathrm{~h}$. Nuclei and the other organelles in the cells, however, retained morphological integrity at the infection sites and also in the adjacent region, indicating that the infected cells were still living (Fig. 1A). By 72 to $84 \mathrm{~h}$, nuclei in cells adjacent to one containing fungal haustoria showed an increase of heterochromatin, but other organelles in the adjacent cells remained structurally intact (Fig. 1B). Strong chromatin condensation accompanied by morphologically abnormal chloroplasts, which typically occur concomitantly in apoptotically dying oat cells, was observed $96 \mathrm{~h}$ after inoculation in the adjacent cells (Fig. 1C). At this time, DNA cleavage and DNA laddering were detected by the electron microscopic (EM)-TUNEL assay (Fig. 1D) and agarose gel electrophoresis (data not shown), respectively. These data indicated that an apoptotic response also occurred in the compatible oat-rust interaction, although it started at a later stage of infection than in the incompatible interaction. Consequently, the fungus seemed to have successfully formed a mycelial colony within the "dying" leaf tissues.

\section{Cell death induced}

by a facultative biotroph, the blast fungus.

Primary leaves of Shokan 1 were inoculated with compatible (Br58) and incompatible ( $\mathrm{Br} 48)$ isolates of the blast fungus Magnaporthe grisea. Four days after inoculation, clear, blastcoalescing lesions were observed in the compatible combination, whereas only a few small brown spots were detected in the incompatible interaction (Fig. 2A). Genomic DNA was extracted from the infected primary leaves 2 to 4 days postinoculation. DNA ladders were detected in both incompatible and compatible combinations (Fig. 3A). More intense DNA fragmentation was observed in the compatible combination than in the incompatible one, probably because more infected and, thus, collapsed cells were present.

Heterochromatin condensation, a hallmark of apoptosis, was also examined by EM observation to give an alternative evaluation of the apoptotic response. We focused on the mesophyll cells immediately beneath the blast-infected epidermal cells. In the incompatible interaction, much more condensed hetero- chromatin was observed in the nuclei of the infected mesophyll cells (Fig. 4B) than in healthy cells (Fig. 4A) $60 \mathrm{~h}$ after inoculation. In the compatible interaction, many infection hyphae were found in intercellular spaces as early as $48 \mathrm{~h}$ after inoculation, and chromatin condensation usually was detected in the mesophyll cells adjacent to the infection hyphae (Fig. 4C). Interestingly, in the oat-blast system, chromatin condensation could be observed earlier in the compatible interaction (48 $\mathrm{h}$ after inoculation) than in the incompatible one $(60 \mathrm{~h}$ after inoculation). This is opposite to the results obtained in the oat-rust system, where chromatin condensation and DNA laddering were observed earlier in oat cells infected with the incompatible race than in those infected with the compatible race.

\section{Cell death induced by pathogenic bacteria.}

Pseudomonas syringae pv. atropurpurea, the causal agent of halo on oats, produces the phytotoxin coronatine (Bender et al. 1999), and $P$. syringae pv. coronafaciens, which causes stripe blights on oats, secretes tabtoxin (Bender et al. 1999; Stewart 1971). These phytotoxins are known to injure plant cells and to be involved in disease development and symptoms (Bender et al. 1999; Zhao et al. 2001). We employed two toxin-producing strains ( $P$. syringae pv. atropurpurea, MAFF 301309 [COR $\left.{ }^{+}\right]$ and $P$. syringae pv. coronafaciens MAFF $\left.301314\left[\mathrm{TAB}^{+}\right]\right)$and one coronatine-defective mutant $(P$. syringae pv. atropurpurea MAFF $\left.301313\left[\mathrm{COR}^{-}\right]\right)$. The coronatine-producing strain $\left(\mathrm{COR}^{+}\right)$induced severe water soaking symptoms on primary oat leaves 3 days after inoculation, whereas the coronatine-defective mutant strain $\left(\mathrm{COR}^{-}\right)$did not cause any symptoms (Fig. $\left.2 \mathrm{~B}\right)$. To examine whether these phytotoxins induce cell death through an apoptotic process, nuclear DNA laddering assays and EM observation were carried out. DNA laddering was detected in the $\mathrm{COR}^{+}$-inoculated leaves, but not in $\mathrm{COR}^{-}$-inoculated ones (Fig. 3B). DNA laddering also was detected in oat leaves inoculated with the $\mathrm{TAB}^{+}$strain (data not shown).

No chromatin condensation was observed in oat leaves inoculated with the $\mathrm{COR}^{-}$mutant, although electron-dense appositions were detected in the mesophyll cells beneath the cell wall
A

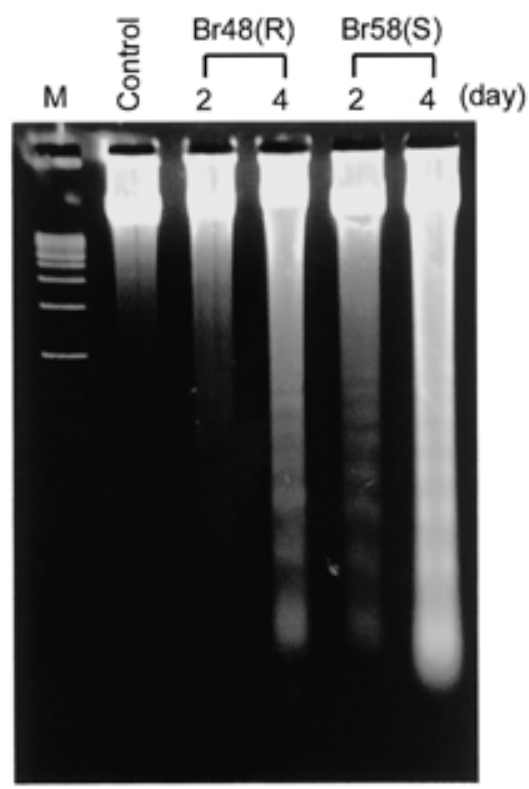

B

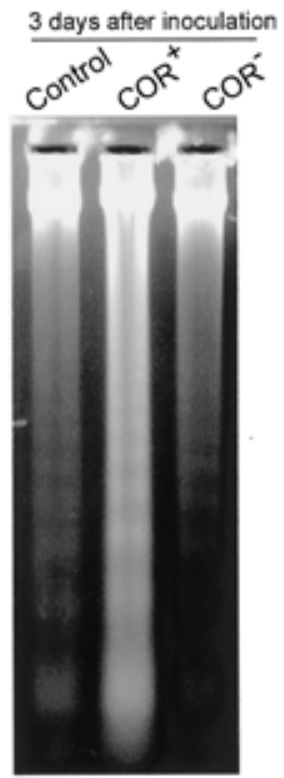

C

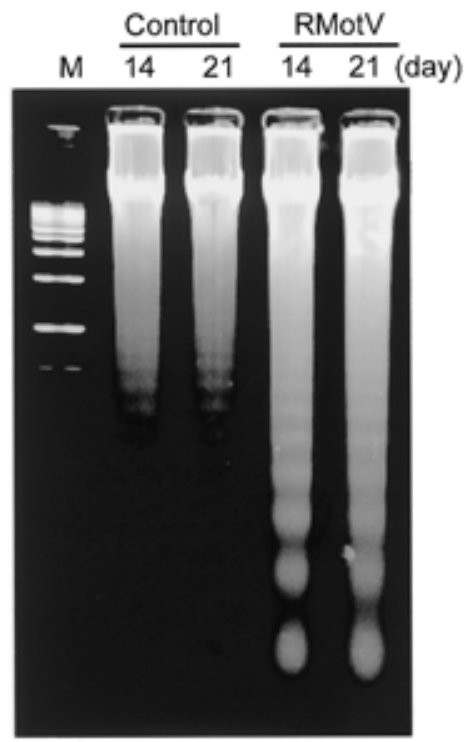

Fig. 3. Induction of DNA laddering in oat leaves inoculated with A, Magnaporthe grisea, Triticum isolate Br48, and Avena isolate Br58, B, coronatine producing wild-type strain $\left(\mathrm{COR}^{+}\right)$and coronatine-defective mutant $\left(\mathrm{COR}^{-}\right)$of Pseudomonas syringae pv. atropurpurea, and $\mathbf{C}$, Ryegrass mottle virus. Primary (A and $\mathbf{B})$ and secondary $(\mathbf{C})$ leaves were used for genomic DNA extraction. $\mathbf{M}=$ size markers. 
attacked by the bacteria (Fig. 5A). In contrast, the mesophyll cells infected with the toxin-producing strains, $\mathrm{COR}^{+}$and $\mathrm{TAB}^{+}$, showed clear chromatin condensation (Fig. 5B and E). In those tissues, the intercellular space was filled with the bacterial cells (Fig. 5D). Further, the condensed chromatin was labeled with immunogold particles by the EM-TUNEL assay, indicating that DNA cleavage occurred in the heterochromatin region (Fig. 5C).

\section{Cell death induced by Ryegrass mottle virus.}

Ryegrass mottle virus (RMotV), which readily infects oats (Toriyama et al. 1983), was employed to investigate virus-induced cell death. Primary oat leaves were mechanically inoculated with RMotV-infected plant sap. At 2 to 3 weeks after inoculation, typical symptoms appeared in the secondary leaves of the inoculated oat seedlings (Fig. 2C). The RMotVinfected oat plants became slightly stunted and the leaves showed chlorotic mottling as described previously (Toriyama et al. 1983). The primary leaves withered 2 weeks after inoculation even in the control (mock) plants; therefore, we collected the secondary leaves to extract genomic DNA and simultaneously fixed them for EM observation. Clear DNA laddering was observed in the inoculated oat seedlings but not in the control (Fig. 3C). By EM observation, a large number of virus particles were detected in the cytoplasm in the relatively green portion of the infected leaves (Fig. 6A and B). The virus particles were approximately $28 \mathrm{~nm}$ in diameter, which exactly matched to the size of RMotV described previously (Toriyama et al. 1983). Chromatin condensation in nuclei was detected mainly in the yellow portion of the infected leaves, which is adjacent to the green portion wherein RMotV accumulated (Fig. 6C). DNA cleavage in the nuclei of the RMotV-infected cells also was indicated by the distribution of EM-TUNELpositive gold particles in the condensed chromatin (Fig. 6D), suggesting that apoptotic cell death occurred mainly in the yellow portion of RMotV-infected oat leaves.

\section{DISCUSSION}

Using several different plant-pathogen systems, it has been demonstrated that host cell death during pathogen attack exhibits hallmark characteristics of apoptosis or programmed cell death (PCD) not only in incompatible interactions but also in compatible interactions (Dickman et al. 2001; Ryerson and Heath 1996; Tada et al. 2001; Wang et al. 1996). However, there is little data concerning whether or not plant cell death triggered by various different stimuli occurs via a common suicide process in a given system. Therefore, we examined in detail the processes of cell death induced by various classes of pathogens showing different compatibility with a common host plant. The summary of our study is presented in Table 1. Most of the apoptotic features we examined were observed in oat plants infected with each of the pathogens used, suggesting that apoptotic cell death is a common and general response to pathogen attack in oats.

We assume at least three possible causes of apoptotic cell death in oats. One is HR triggered in the host cell via the perception of an avirulence product of the pathogen, as has been described in various incompatible plant-microbe interactions. Rapid cell death observed in the incompatible rust-oat interaction probably is included in this criterion.

Another cause can be phytotoxins secreted by compatible pathogens. Host-specific toxins (HST) such as AAL-toxin and victorin have been shown to be essential for the pathogenicity of the pathogens and for induction of apoptotic cell death in the host plants (Tada et al. 2001; Wang et al. 1996). Apoptotic cell death provoked by facultative biotrophic pathogens also could occur by the action of toxins. There have been several reports that $M$. grisea produces phytotoxins such as pyrichalasin H (Nukina and Namai 1991; Tsurushima et al. 1999), pyriculariol (Nukina et al. 1981), and tenuazonic acid (Lebrun et al. 1990). Similarly, P. syringae produces chlorosisinducing phytotoxins, coronatine and tabtoxin (Bender et al. 1999). Coronatine was mobile in the infected plant tissues, and therefore detected even in healthy tissue adjacent to the bacterial lesions (Zhao et al. 2001). These toxins seem to be associated with the induction of the apoptotic cell death in oats, thus leading to successful infection in the compatible interaction. Recently, it has been shown that Sclerotinia sclerotiorum induced disease in tobacco by activating a plant PCD pathway because transgenic tobacco plants expressing animal antiapoptotic genes, such as Bcl-2, Bcl-xl, CED-9, and Op-IAP, exhibited heritable resistance to the necrotrophic fungal pathogen (Dickman et al. 2001). Involvement of the fungal phytotoxin cercosporin in the induction of PCD was implicated (Dickman et al. 2001). It might be common for plant pathogens to turn on the "death switch" of the host cell by the action of their toxins, consequently enabling successful infection.

The other cause we assume is fatal damage of the cell caused by pathogen infection. This includes physical wounding, a defi-
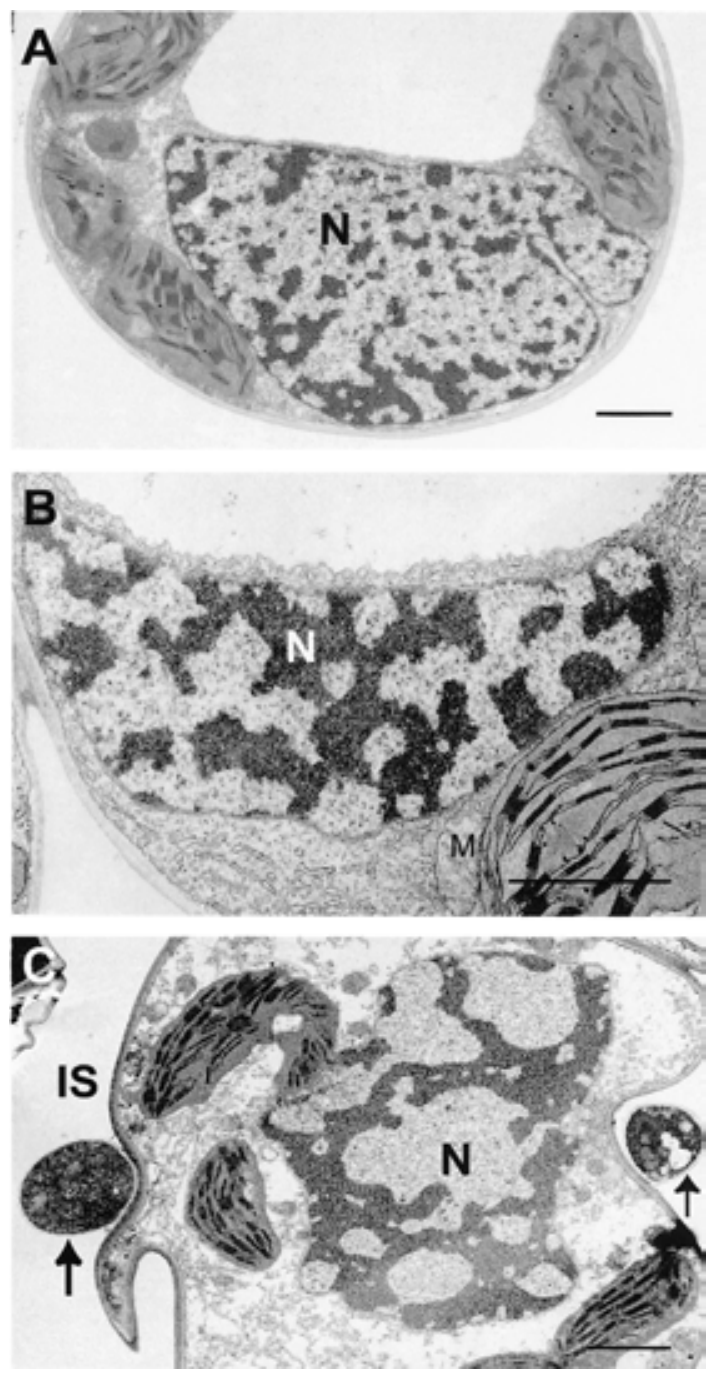

Fig. 4. Ultrastructural changes in oat mesophyll cells during blast pathogen infections. A, Cell $48 \mathrm{~h}$ after treatment with $0.01 \%$ Tween 20 solution. B, Cell $60 \mathrm{~h}$ after inoculation with the Triticum isolate Br48. C, Cell $48 \mathrm{~h}$ after inoculation with the Avena isolate Br58. Note fungal hyphae (arrows) in the intercellular space in C. IS = intercellular space, $\mathrm{N}=$ nucleus, $\mathrm{M}=$ mitochondrion. $\mathrm{Bar}=2 \mu \mathrm{m}$. 
cit of nutrients, and malfunction of the cellular metabolism. Plants may have an intrinsic mechanism, as a homeostatic response, to eliminate cells suffering fatal damage by triggering a suicide program. Cell death induced by compatible obligate parasites such as rust and RMotV may belong to this category because these pathogens do not provoke HR or produce known narcotizing toxins. It was interesting to observe that RMotV-inducing cell death was mainly detected in the yellowish portion of the infected leaves that is adjacent to the green region where the cells were alive and many viral virions accumulated. This is clearly different from the report on $\mathrm{N}$ gene-mediated programmed cell death induced by tobacco mosaic virus in tobacco plants (Whitham et al. 1994), in which the virus elicited HR in the inoculated cells, thus restricting movement of the virus to uninoculated leaves. RMotV-inducing apoptotic cell death in the surrounding yellowish portion might be caused by malfunction of the cellular metabolism or a deficit of nutrients due to viral infection, even though we cannot rule out the possibility that apoptotic cell death might be a resistance response to further infection of the virus.

However, as mentioned above, once the apoptotic cell program was triggered by any of the causes, the process of the cell death in oats was morphologically and biochemically hardly distinguishable by our approach, suggesting a common underlying cell death pathway. The perceptible major difference among the cell death processes induced by the various pathogens was the timing of cell death and the number of dying cells. In the case of the obligate parasite rust, typical apoptotic responses were rapidly induced in the incompatible interaction as early as $24 \mathrm{~h}$ after inoculation (Tada et al. 2001; N. Yao, H. Nakayashiki, Y. Tosa, S. Mayama, unpublished data), whereas those responses were detectable later at $96 \mathrm{~h}$ after inoculation in the incompatible interaction (Fig. 1; Mayama et al. 2001). On the other hand, M. grisea, a facultative biotrophic fungus, induced the apoptotic cell responses significantly earlier in the compatible interaction ( $48 \mathrm{~h}$ postinoculation) than in the incompatible interaction ( $60 \mathrm{~h}$ postinoculation). Actually, many more mesophyll cells were affected and killed by vigorous growth of infection hyphae in the oat tissue infected with the compatible blast fungus. The difference in the host responses to those pathogens is interesting and seems to be due to the infection strategies of the pathogens. Obligate parasites can infect only live cells; therefore, they need to "sneak into" the host cell without causing any damage provoking apoptotic cell death. It also is possible that compatible obligate parasites may secrete some anti-apoptotic metabolic substance or protein as reported in animal viruses (Messeud-Petit et al. 1998; Ray and Pickup 1996). Consequently, cell death did not occur
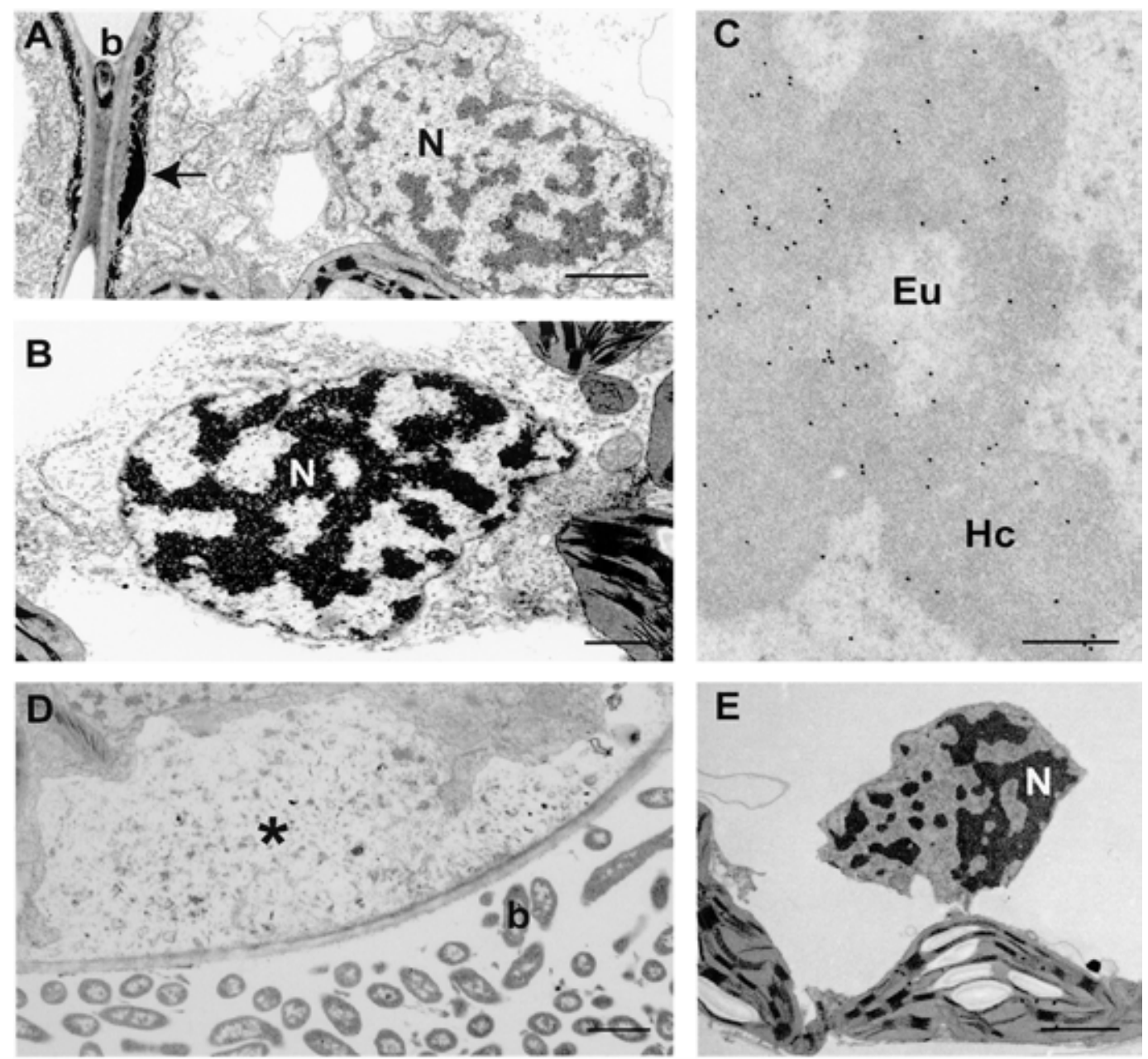

Fig. 5. Ultrastructural changes in oat mesophyll cells during bacterial infections. A, Cells 72 h after inoculation with the COR mutant of Pseudomonas syringae pv. atropurpurea. Note that a bacterium was arrested in extracellular apposition, and a normal nucleus and heavily electron-dense wall apposition (arrow) were observed. B, Nucleus of a mesophyll cell $72 \mathrm{~h}$ after inoculation with the $\mathrm{COR}^{+}$strain. Note the intense heterochromatin condensation. $\mathbf{C}$, Electron microscopic-terminal deoxynucleotidyl transferase-mediated UTP end labeling analysis of the immunolocalization of DNA strand breaks in the same sample as shown in B. D and E, Cells $72 \mathrm{~h}$ after inoculation with the $\mathrm{TAB}^{+}$strain of P. syringae pv. coronafaciens. Note a large wall-apposition (asterisk) and bacteria filling up the intercellular space in D, and nucleus with condensed chromatin in E; b = bacterium, Eu = euchromatin, Hc = heterochromatin, $\mathrm{N}=$ nucleus. $\mathrm{Bar}=2 \mu \mathrm{m}(\mathrm{A}, \mathrm{B}, \mathrm{D}$, and $\mathrm{E})$ and $200 \mathrm{~nm}(\mathrm{C})$. 
until the later stage of infection by compatible obligate parasites, whereas hypersensitive cell death was induced at the early stage of infection in incompatible interactions. Facultative biotrophic pathogens, on the other hand, seem to make their infection successful by inducing a collapse in the host cell, probably by the action of the phytotoxins they produce. Therefore, more and rapid cell death of the host may occur in the compatible interaction.

\section{MATERIALS AND METHODS}

\section{Plant materials.}

Oat (Avena sativa L.) cultivar Shokan 1 was used as a test plant throughout the experiments. Seed of Shokan 1 were soaked in water for $12 \mathrm{~h}$, then sown in vermiculite and grown in a growth chamber under a 16 -h photoperiod at $20^{\circ} \mathrm{C}$. Sevenday-old primary leaves were used for all inoculation experiments.

\section{Fungal isolates and inoculation.}

The race 203 uredospores of the oat rust fungus, Puccinia coronata f. sp. avenae, were produced on compatible host cultivar Shokan 1. Uredospores (10 mg) mixed with $90 \mathrm{mg}$ of talc were sprayed onto both surfaces of the primary leaves. Inoculated seedlings were incubated in a humid chamber at $20^{\circ} \mathrm{C}$ in the dark for $12 \mathrm{~h}$ and then transferred to the conditions mentioned above.

The blast fungal isolates employed were Magnaporthe grisea, Br48 from wheat (Triticum aestivum (L.) Thell.) (Murakami et al. 2000; Urashima et al. 1993), and Br58 from oats (Avena sativa L.) (Kusaba et al. 1999). They were cultured on oatmeal agar media ( $40 \mathrm{~g}$ of oat flakes, $5 \mathrm{~g}$ of sucrose, and $20 \mathrm{~g}$ of agar per liter) at $24^{\circ} \mathrm{C}$ for 1 week. Aerial mycelia were removed with a sterile swab and sporulation was induced by further incubation under near-ultraviolet light $(360 \mathrm{~nm}$, $40 \mathrm{~W}$ ) for 5 days. For inoculation, the concentration of conidia was adjusted to $6 \times 10^{5} \mathrm{ml}^{-1}$ in a spraying suspension with $0.01 \%$ Tween 20 as described previously (Murakami et al. 2000). After inoculation, the seedlings were kept for $18 \mathrm{~h}$ in a moist chamber, and then incubated in a growth chamber under a 16 -h photoperiod at $20^{\circ} \mathrm{C}$. Samples were taken for DNA extraction and electron microscopy at various times.

\section{Bacterial strains and inoculation.}

Pseudomonas syringae pv. atropurpurea, MAFF strain 301309 which produces a phytotoxin coronatine $\left(\mathrm{COR}^{+}\right)$,
MAFF strain 301313, which is a COR-defective (COR ${ }^{-}$) mutant (Ichihara et al. 1977) and P. syringae pv. coronafaciens strain MAFF $301314\left(\mathrm{TAB}^{+}\right)$which produces another phytotoxin tabtoxin, were kindly provided by K. Nishiyama (National Institute of Agro-Environmental Sciences, Tsukuba, Japan). Bacterial cultures were grown overnight in King's B broth (KB) medium at $30^{\circ} \mathrm{C}$ and adjusted to $10^{8} \mathrm{CFU} / \mathrm{ml}$ in 50 $\mathrm{mM}$ Na-phosphate buffer ( $\mathrm{pH} 7.5)$. Oat primary leaves were inoculated by infiltration of the bacterial suspension or buffer (as a control) with 1-ml blunt syringes. After inoculation, plants were incubated in a growth chamber under a $16 \mathrm{~h}$ photoperiod at $20^{\circ} \mathrm{C}$. The inoculated leaves were used for DNA extraction and electron microscopic analysis.

\section{Virus strain and inoculation.}

RMotV-infected leaves of Lolium multiflorum or Triticum aestivum were kindly provided by S. Toriyama (The Ministry of Agriculture, Forestry and Fisheries of Japan). The infected leaves were frozen in liquid nitrogen and stored at $-80^{\circ} \mathrm{C}$. For inoculation, RMotV-infected tissue $(5 \mathrm{~g})$ was ground with 50 $\mathrm{mM}$ Na-phosphate buffer ( $\mathrm{pH} 7.5$ ). Primary oat leaves were mechanically inoculated with the RMotV-infected plant sap and incubated in a growth chamber under a 16-h photoperiod at $20^{\circ} \mathrm{C}$. At 2 or 3 weeks after inoculation, the second leaves were subjected to DNA extraction and EM observation.

\section{DNA extraction and analysis.}

Plant DNA was extracted by the cetyltrimethylammonium bromide (CTAB) method as described previously (Tada et al. 2001). The inoculated oat leaf segments were ground with liquid nitrogen into a fine powder, incubated for $30 \mathrm{~min}$ at $65^{\circ} \mathrm{C}$ in $2 \%$ CTAB solution (100 mM Tris- $\mathrm{HCl}, \mathrm{pH} 8.0,1.4 \mathrm{M} \mathrm{NaCl}$, $20 \mathrm{mM}$ EDTA, 2\% CTAB), and mixed with an equal volume of chloroform:isoamyl alcohol mixture (24:1). After gently shaking, the mixture was centrifuged for $15 \mathrm{~min}$ at $10,000 \times g$. The chloroform:isoamyl alcohol extraction was repeated twice. Total DNA was precipitated by the addition of $1 \%$ CTAB solution (50 mM Tris- $\mathrm{HCl}, \mathrm{pH} 8.0,10 \mathrm{mM}$ EDTA, 1\% CTAB) to the supernatant. After centrifugation, the pellet was dissolved in $1 \mathrm{M} \mathrm{CsCl}$ and subjected to alcohol precipitation with a twofold volume of $100 \%$ ethanol. DNA was recovered by centrifugation for $10 \mathrm{~min}$ at $10,000 \times g$ followed by washing with $70 \%$ ethanol, and was dissolved in Tris-EDTA buffer containing Rnase at $0.1 \mathrm{mg} / \mathrm{ml}$. After incubation at $37^{\circ} \mathrm{C}$ for 30 min, phenol extraction and ethanol precipitation were per-

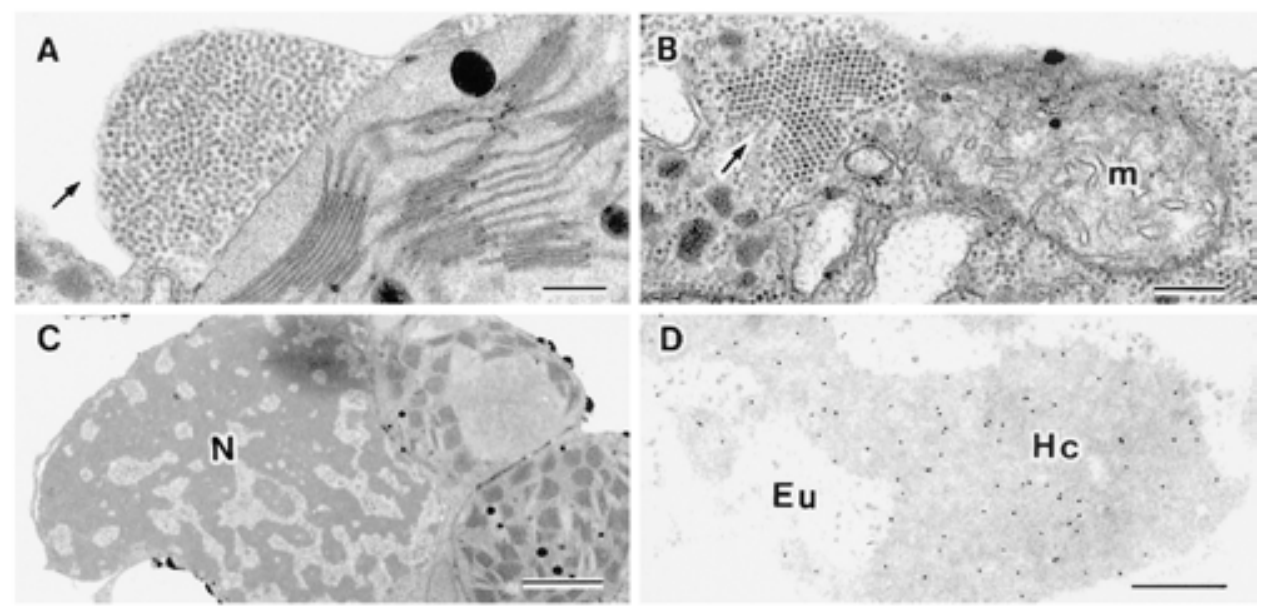

Fig. 6. Ultrastructural changes in mesophyll cells of oat leaves infected with Ryegrass mottle virus 14 days after inoculation. A and B, Virus particles (arrows) in the cytoplasm of oat cells in the green portion of the secondary leaf. C, Chromatin condensation and D, DNA cleavage detected by electron microscopic-terminal deoxynucleotidyl transferase-mediated UTP end labeling in the oat cells located on the yellow portion of the secondary leaf. Eu = euchromatin, $\mathrm{Hc}=$ heterochromatin, $\mathrm{m}=$ mitochondrion, $\mathrm{N}=$ nucleus. $\mathrm{Bar}=200 \mathrm{~nm}(\mathrm{~A}, \mathrm{~B}$, and $\mathrm{D})$ and $1 \mu \mathrm{m}(\mathrm{C})$. 
Table 1. Induction of apoptotic responses in mesophyll cells at the infection sites of oat leaves by various pathogens

\begin{tabular}{|c|c|c|c|c|}
\hline Pathogen & Interaction $^{\mathrm{a}}$ & DNA laddering ${ }^{b}$ & Chromatin condensation $^{b}$ & EM-TUNEL $^{c}$ \\
\hline \multicolumn{5}{|l|}{ Puccinia coronata f. sp. avenae } \\
\hline$($ race 226$)$ & - & + & + & + \\
\hline (race 203) & + & + & + & + \\
\hline \multicolumn{5}{|l|}{ Magnaporthe grisea } \\
\hline Br48 (Triticum isolate) & - & + & + & ND \\
\hline Br58 (Avena isolate) & + & + & + & + \\
\hline \multicolumn{5}{|c|}{ Pseudomonas syringae pv. atropurpurea } \\
\hline (coronatine-defective strain) & NR & - & - & - \\
\hline (coronatine-producing strain) & + & + & + & + \\
\hline \multicolumn{5}{|l|}{ P. syringae pv. coronafaciens } \\
\hline (tabtoxin-producing strain) & + & + & + & ND \\
\hline Ryegrass mottle virus (RMotV) & + & + & + & + \\
\hline
\end{tabular}

${ }^{a}$ Incompatible (-) and compatible (+) interactions with oat cv. Shokan 1. NR = no reaction.

${ }^{\mathrm{b}}$ Presence $(+)$ or absence $(-)$ of DNA laddering and chromatin condensation in oat cv. Shokan 1 . ND = not determined.

${ }^{\mathrm{c}}$ EM-TUNEL = Electron microscopic-terminal deoxynucleotidyl transferase-mediated UTP end labeling.

formed to recover DNA. The DNA samples were detected on a $2 \%$ agarose gel after staining with ethidium bromide at 0.5 $\mu \mathrm{g} / \mathrm{ml}$. DNA ladders were photographed with an Image Saver AE-6905C (ATTO Corporation, Tokyo).

\section{Ultrastructural analysis and EM-TUNEL assay.}

Leaf segments were prefixed in $2.5 \%$ glutaraldehyde with $0.1 \mathrm{M}$ cacodylate buffer and postfixed with $1 \%$ osmium tetroxide. The samples were further dehydrated in ethanol and embedded in Epon 812 resin. Then the ultrathin sections were stained with $2 \%$ uranyl acetate $(20 \mathrm{~min})$ and, afterward, by lead citrate (10 min). Detection of DNA cleavage was performed with the EM-TUNEL procedure using ApopTag Plus Fluorescein in situ Apoptosis Detection Kit (Intergen, Burlington, MA, U.S.A.) as described previously (Yao et al. 2001). The sections were photographed in a transmission electron microscope (Hitachi-7100; Hitachi, Tokyo) at an accelerating voltage of $75 \mathrm{kV}$.

\section{ACKNOWLEDGMENTS}

This work was supported in part by a Grant-in-Aid for Scientific Research (No. 12052215) and special coordination funds for promoting science and technology and by fellowships to N. Yao from the Ministry of Education, Science, Sports and Culture of Japan.

\section{LITERATURE CITED}

Bender, C. L., Alarcon-Chaidez, F., and Gross, D. C. 1999. Pseudomonas syringae phytotoxins: Mode of action, regulation, and biosynthesis by peptide and polyketide synthetases. Microbiol. Mol. Biol. Rev. 63:266292

Dangl, J. L., Dietrich, R. A., and Richberg, M. H. 1996. Death don't have no mercy: Cell death programs in plant-microbe interactions. Plant Cell 8:1793-1807.

del Pozo, O., and Lam, E. 1998. Caspases and programmed cell death in the hypersensitive response of plants to pathogens. Curr. Biol. 8:11291132.

Dickman, M. B., Park, Y. K., Oltersdorf, T., Li, W., Clemente, T., and French, R. 2001. Abrogation of disease development in plants expressing animal antiapoptotic genes. Proc. Natl. Acad. Sci. U.S.A. 98:69576962

Fisher, D. E. 1994. Apoptosis in cancer therapy: Crossing the threshold. Cell 78:539-542.

Gilchrist, D. G. 1998. Programmed cell death in plant disease: The purpose and promise of cellular suicide. Annu. Rev. Phytopathol. 36:393-414.

Gougeon, M.-L., Ledru, E., Lecoeur, H., and Garcia, S. 1998. T cell apoptosis in HIV infection: Mechanisms and relevance for AIDS pathogenesis. Pages 233-248 in: Apoptosis: Mechanisms and Role in Disease. S. Kumar, ed. Springer, New York.

Greenberg, J. T. 1997. Programmed cell death in plant pathogen interactions. Annu. Rev. Plant Physiol. Plant Mol. Biol. 48:525-545.

Heath, M. C. 1998. Apoptosis, programmed cell death and the hypersensitive response. Eur. J. Plant Pathol. 104:117-124.
Heath, M. C. 2000. Hypersensitive response-related death. Plant Mol Biol. 44:321-334.

Hirpara, J. L., Clement, M.-V., and Pervaiz, S. 2001. Intracellular acidification triggered by mitochondrial-derived hydrogen peroxide is an effector mechanism for drug-induced apoptosis in tumor cells. J. Biol. Chem. 276:514-521.

Ichihara, A., Shiraishi, K., Sato, H., Sakamura, S., Nishiyama, K., Sakai, R., Furusaki, A., and Matsumoto, T. 1977. The structure of coronatine. J. Am. Chem. Soc. 99:636-637.

Kusaba, M., Eto, Y., Don, L. D., Nishimoto, N., Tosa, Y., Nakayashiki, H. and Mayama, S. 1999. Genetic diversity in Pyricularia isolates from various hosts revealed by polymorphisms of nuclear ribosomal DNA and the distribution of the MAGGY retrotransposon. Ann. Phytopathol. Soc. Jpn. 65:588-596.

Lam, E., Kato, N., and Lawton, M. 2001. Programmed cell death, mitochondria and the plant hypersensitive response. Nature 411:848-853.

Lebrun, M. H., Dutfoy, F., Gaudemer, F., Kunesch, G., and Gaudemer, A. 1990. Detection and quantification of the fungal phytotoxin tenuazonic acid produced by Pyricularia oryzae. Phytochemistry 29:3777-3783.

Martin, S. J., and Green D. R. 1995. Protease activation during apoptosis: Death by a thousand cuts? Cell 82:349-352.

Mayama, S., Tada, Y., Hata, S., Takada, Y., Yao, N., Mori, T., Yang, Q., Betsuyaku, S., Nakayashiki, H., Tosa, Y., and Park, P. 2001. Apoptotic response in defense of oats to infections and elicitors. Pages 220-228 in: Delivery and Perception of Pathogen Signals to Plants. N. T. Keen, S. Mayama, J. E. Leach, and S. Tsuyumu, eds. American Phytopathological Society Press, St. Paul, MN, U.S.A.

Messeud-Petit, F., Gelfi, J., Delverdier, M., Amardeilh, M. F., Py, R. Sutter, G., and Bertagnoli, S. 1998. Serp2, an inhibitor of the interleukin-1 beta-converting enzyme, is critical in the pathobiology of myxoma virus. J. Virol. 72:7830-7839.

Mittler, R., and Lam. E. 1995. Identification, characterization, and purification of a tobacco endonuclease activity induced upon hypersensitive response cell death. Plant Cell 7:1951-1962.

Morel, J. B., and Dangl, J. L. 1997. The hypersensitive response and the induction of cell death in plants. Cell Death Differ. 4:1318-1328.

Murakami, J., Tosa, Y., Kataoka, T., Tomita, R., Kawasaki, J., Chuma, I., Sesumi, Y., Kusaba, M., Nakayashiki, H., and Mayama, S. 2000. Analysis of host species specificity of Magnaporthe grisea toward wheat using a genetic cross between isolates from wheat and foxtail millet. Phytopathology 90:1060-1067.

Navarre, D. A., and Wolpert, T. J. 1999. Victorin induction of an apoptotic/senescence-like response in oats. Plant Cell 11:237-249.

Nukina, M., and Namai, T. 1991. Production of pyricharasin H, a phytotoxic metabolite, from different isolates of Pyricularia grisea and from other isolates of Pyricularia spp. Agric. Biol. Chem. 55:1899-1900.

Nukina, M., Sassa, T., Ikeda, M., Umezawa, T., and Tasaki, H. 1981. Pyriculariol, a new phytotoxic metabolite of Pyricularia oryzae Cavara. Agric. Biol. Chem. 45:2161-2162.

Pontier, D., Balague, C., and Roby, D. 1998. The hypersensitive response. A programmed cell death associated with plant resistance. Mol. Biol. Genetics 321:721-734.

Ray, C. A., and Pickup, D. J. 1996. The mode of death of pig kidney cells infected with cowpox virus is governed by the expression of the crmA gene. Virology 217:384-391.

Richberg, M. H., Aviv, D. H., and Dangl, J. 1998. Dead cells do tell tales. Curr. Opinion. Plant Bio. 1:480-485.

Ryerson, D. E., and Heath, M. C. 1996. Cleavage of nuclear DNA into oligonucleosomal fragments during cell death induced by fungal infection 
or by abiotic treatments. Plant Cell 8:393-402.

Stewart, W. W. 1971. Isolation and proof of structure of wildfire toxin Nature 229:174-178.

Tada, Y., Hata, S., Takata, Y., Nakayashiki, H., Tosa, Y., and Mayama, S. 2001. Induction and signaling of an apoptotic response typified by DNA laddering in the defense response of oats to infection and elicitors. Mol. Plant-Microbe Interact. 14:477-486.

Toriyama, S., Mikoshima, Y., and Doi, Y. 1983. Ryegrass mottle virus, a new virus from Lolium multiflorum in Japan. Ann. Phytopathol. Soc. Jpn. 49:610-618.

Tsurushima, T., Kawashima, K., Murakami, J., Don, L. D., Nakayashiki, H., Tosa, Y., and Mayama, S. 1999. Pyricharasin H production and pathogenicity of Magnaporthe grisea on crabgrass. Page 77 in: Mol. Plant-Microbe Interact. 9th Int. Congr. Book Abstr. Amsterdam.

Urashima, A. S., Igarashi, S., and Kato, H. 1993. Host range, mating type, and fertility of Pyricularia grisea from wheat in Brazil. Plant Dis. 77:1211-1216.

Veis, D. J., Sorenson, C. M., Shuter, J. R., and Korsmeyer, S. J. 1993. Bcl2-deficient mice demonstrate fulminant lymphoid apoptosis, polycystic kidneys, and hypopigmented hair. Cell 75:229-240.

Wang, H., Li, J., Bostock, R. M., and Gilchrist, D. G. 1996. Apoptosis: A functional paradigm for programmed plant cell death induced by a hostselective phytotoxin and invoked during development. Plant Cell 8:375391.

Whitham, S., Dinesh-Kumar, S. P., Choi, D., Hehl, R., Corr, C., and Baker, B. 1994. The product of the tobacco mosaic virus resistance gene $\mathrm{N}$ : Similarity to toll and the interleukin-I receptor. Cell 78:1101-1115.

$\mathrm{Xu}$, P., and Roossinck, M. J. 2000. Cucumber mosaic virus D satellite RNA-induced programmed cell death in tomato. Plant Cell 12:1079. 1092.

Yao, N., Tada, Y., Park, P., Nakayashiki, H., Tosa, Y., and Mayama, S. 2001. Novel evidence for apoptotic cell response and differential signals in chromatin condensation and DNA cleavage in victorin-treated oats. Plant J. 28:13-26.

Zhao, Y. F., Jones, W. T., Sutherland, P., Palmer, D. A., Mitchell, R. E. Reynolds, P. H. S., Damicone, J. P., and Bender, C. L. 2001. Detection of the phytotoxin coronatine by ELISA and localization in infected plant tissue. Physiol. Mol. Plant Pathol. 58:247-258. 